\title{
A ampliaçáo do conceito de refugiado: o caso da Venezuela e dos deslocados ambientais
}

\author{
Ampliación del concepto de refugiado: el caso de Venezuela \\ y los desplazados ambientales
}

\author{
Broadening the refugee concept: The case of Venezuela \\ and the environmentally displaced persons
}

Jorge Jurado ${ }^{* *}$

Fernando Rei ${ }^{* * *}$

Data de recepção: 3 de outubro de 2019 Data de aprovação: 4 de dezembro de 2019

\section{RESUMO}

O regime internacional de proteção dos refugiados nasceu como consequência do fenômeno das migraçóes em massa, especialmente as derivadas de diferentes confrontos bélicos. Entretanto, na atualidade, massivos movimentos de pessoas decorrentes de causas múltiplas fazem com que o conceito clássico de refugiados, baseado na perseguição por motivos de raça, religião, nacionalidade, grupo social ou opinióes políticas seja revisitado. A impossibilidade

\footnotetext{
Este artigo é produto do projeto de pesquisa "A ampliação do conceito de refugiado: o caso da Venezuela e dos deslocados ambientais", no âmbito do Programa de Doutorado Ambiental Internacional da Universidade Católica de Santos, Brasil.

Citar como Jurado, J. y Rei, F. (2020). A ampliação do conceito de refugiado: o caso da Venezuela e dos deslocados ambientais. Via Inveniendi et Iudicandi, 15(1), 13-39. Dor: https://doi.org/10.15332/19090528/5740

** Direito dos Recursos Naturais pela Universidade Externado da Colômbia. Doutorando em Direito Ambiental Internacional pela Universidade Católica de Santos. Bolsista do Programa Estudantes-Convênio de PósGraduação, do Conselho Nacional de Desenvolvimento Científico e Tecnológico, Brasil. orcid: https://orcid. org/0000-0002-5016-0788 e-mail: jorgeluis_jurado@hotmail.com

*** Professor associado do Programa de Doutorado em Direito Ambiental Internacional da Universidade Católica de Santos. Professor titular da Fundação Armando Alvares Penteado. Diretor científico da Sociedade Brasileira de Direito Internacional do Meio Ambiente. ORCID: https://orcid.org/0000-0001-5870-3305 e-mail: fernandorei@ig.com.br
} 
de desenvolver uma vida em condiçóes condignas em seu país de nacionalidade coloca como objeto de discussão e estudo a situação dos nomeados migrantes econômicos e dos deslocados ambientais, como possíveis casos de ampliação do conceito de refugiado, cujo estudo é o objetivo principal deste artigo. $\mathrm{O}$ método de pesquisa usado foi o teórico-dedutivo, porque, para o desenvolvimento do artigo, se partiu do entendimento geral do conceito de refugiado para, posteriormente, analisar aqueles casos específicos de migraçóes em massa que, baseados em posiçóes doutrinárias e nos contextos sociopolíticos, são o fundamento da ampliação do conceito em questão. Uma conclusão geral sustenta que, se bem a concepção clássica de refugiado não permitiria a inclusão de outras pessoas em condiçôes similares, existem novas realidades que devem ser analisadas a fim de alcançar uma proteçáo em condiçóes igualitárias, como acontece com os migrantes econômicos e os deslocados ambientais. A pesquisa apresentada pretende contribuir para o debate sobre as reformas necessárias em algumas regulaçóes importantes e tradicionais do Direito Internacional, a partir da aplicação dos princípios de cooperação e solidariedade num cenário global cada vez mais complexo.

Palavras-chave: refugiados; migrantes econômicos; deslocados ambientais; Direito Internacional; mudanças climáticas.

\section{RESUMEN}

El régimen de protección de los refugiados en el derecho internacional nació como consecuencia del fenómeno de las migraciones masivas, especialmente las derivadas de confrontaciones armadas. Sin embargo, en la actualidad existen diferentes causas para los grandes movimientos de personas, las cuales están haciendo repensar el concepto clásico de refugiado basado en la persecución por motivos de raza, religión, nacionalidad, grupo social y opiniones políticas. La imposibilidad de desarrollar su vida en condiciones dignas en su país de nacionalidad pone como objeto de discusión y estudio la situación de los denominados migrantes económicos y desplazados ambientales, entendidos como posibles casos de ampliación del concepto de refugiado, cuyo estudio es el objetivo del presente artículo. El método de investigación utilizado fue el teórico-deductivo, porque se partió del entendimiento general del concepto de refugiado, para posteriormente analizar aquellos casos específicos de migraciones en masa que, basados en posiciones doctrinarias y la realidad misma, son el fundamento de la propuesta de ampliación del concepto de refugiado. Una conclusión general sostiene que, si bien la concepción clásica de 
refugiado no permitiría la inclusión de otras personas en condiciones similares, existen nuevas realidades que están generando grandes migraciones en masa que deberían ser analizadas con el fin de obtener una protección en condiciones igualitarias, tal como acontece con los migrantes económicos y los desplazados ambientales. La investigación presentada permite aportar al debate sobre las reformas necesarias en algunas regulaciones importantes y tradicionales del derecho internacional en aplicación de los principios de cooperación y solidaridad.

Palabras clave: refugiados; migrantes económicos; desplazados ambientales; derecho internacional; cambio climático.

\section{Abstract}

The refugee protection regime in international law was created as a consequence of the phenomenon of mass migrations, particularly from those resulting from different armed confrontations. However, at present there are different causes for large movements of people, which are driving us to rethink the classic concept of 'refugee' based on persecution due to race, religion, nationality, social group, and political opinions. The impossibility to develop their life in dignified conditions in their country of nationality raises as an object of discussion and study the situation of the so-called economic migrants and environmentally displaced persons, understood as possible cases of expansion of the refugee concept and whose study is the main objective of this article. The research method used was the theoretical-deductive one, because the development of the article started with the general understanding of the concept of refugee to later analyze those specific cases of mass migrations that, based on doctrinal positions and reality itself, are the basis of the proposal to broaden the refugee concept. A general conclusion is that, although the classical conception of refugee would not allow the inclusion of other people in similar conditions, there are new realities that are generating large mass migrations that should be analyzed in order to obtain protection in equal conditions, as in the case of economic migrants and environmentally displaced persons. The research presented allows us to contribute to the debate on the necessary reforms in some of the most important and traditional regulations of international law in application of the principles of cooperation and solidarity.

Keywords: refugees; economic migrants; environmentally displaced; international law; climate change. 


\section{INTRODUÇÃO}

O fenômeno migratório faz parte da história da humanidade, já que todos temos alguma relação com eventos migratórios. Isso é muito fácil de perceber no Brasil pela mistura de raças que compóem sua sociedade, refletida em uma grande variedade de costumes, cujas origens são derivadas de diferentes fluxos migratórios.

Muitas das migrações são, entretanto, forçadas e decorrem de diversos conflitos bélicos espalhados pelo planeta, os quais geraram dificuldades e verdadeiras tragédias humanitárias que foram, em seu momento, objeto de estudo e negociaçáo pelos Estados no cenário internacional, com a finalidade de proteger e garantir os direitos dessas pessoas em solo diferente daquele de seu nascimento. Tais pessoas são conhecidas como "refugiados".

No presente, não buscam segurança em outros países apenas pessoas que fogem dos efeitos desses conflitos bélicos ou que buscam proteção em razão de perseguição política. Muitos indivíduos buscam a realização de seus direitos mais básicos, buscam proteção em razão de colapsos ambientais ou simplesmente buscam melhor qualidade de vida. No contexto múltiplo dessas situaçôes, tem-se o ser humano que merece proteção interna e que, em nível internacional, deve contar com um sistema de reconhecimento dos Direitos Humanos (Sousa e Bento, 2013 p. 26).

Nesse sentido, o objeto de estudo deste artigo é o conceito de refugiado, e o objetivo é tentar estabelecer algumas circunstâncias que possam suportar uma revisão, uma ampliação do conceito tradicional contido no Estatuto do Refugiado, criado após a Segunda Guerra Mundial.

O método de pesquisa para a elaboração do artigo foi o teórico-dedutivo, porque, para o seu desenvolvimento, partiu-se do entendimento geral sobre o conceito de refugiado para, posteriormente, analisar aqueles casos específicos de migraçôes em massa que, baseados em posiçóes doutrinárias e na realidade delas no contexto sociopolítico, são o fundamento da ampliaçáo do conceito de refugiado proposta (Tirado, Bedoya e Blanco, 2016).

Nesse sentido, este texto está composto por três diferentes partes. Na primeira, fazse uma contextualizaçáo sobre o Estatuto do Refugiado, partindo de uma breve 
revisão da história dessa instituiçãa, assim como do seu conteúdo atual no Direito Internacional. $\mathrm{Na}$ segunda parte, é estudado o caso dos migrantes econômicos e, especialmente, a situação pela qual atravessam muitos venezuelanos, que já representam uma das maiores migraçóes em massa da América Latina. A finalidade disso é estabelecer a necessidade de ampliação do conceito de refugiado, baseado no desenvolvimento dos princípios de cooperação e solidariedade internacional numa sociedade global cada vez mais complexa.

Finalmente, na terceira seção, é abordada a questão relativa aos nomeados "deslocados ambientais", suas causas e as discussóes geradas pela corrente doutrinária que os considera como refugiados, suportando com clareza uma postura a favor dessa consideração, mas sem deixar de lado aquelas posiçóes que não compartilham essa visão (Patarroyo e Benavides, 2014).

\section{O Estatuto do Refugiado}

Falar de refugiados é fazer referência à própria história da humanidade, pois uma das características fundamentais do homem é sua capacidade de viver em sociedade. Como ser racional, reconhece que, em grande parte, sua subsistência depende dos serviços prestados por outras pessoas, fato notório para quem estuda, por exemplo, a evolução da humanidade e das sociedades.

Segundo Aristóteles, o fato de viver em sociedade faz o homem diferente dos demais animais $^{1}$. É muito comum encontrar, nos livros de História, exemplos relacionados com pessoas expulsas da sua sociedade que, por diversas razóes, procuraram refúgio e proteção em novas aglomeraçóes sociais.

Nesse sentido, para Barreto (2010, p. 12), o fenômeno do refúgio não é novo, porquanto já, na antiguidade, especificamente na Grécia Antiga, em Roma, no Egito e na Mesopotâmia, por razões políticas, religiosas, sociais, culturais ou de gênero, muitas pessoas tiveram que deixar suas comunidades, suas cidades e buscar proteçáo em outros

1 Cf. Aristóteles. A política. (pp. 11). 
povos. O mesmo autor indica que, naquela época, o refúgio era marcado pelo caráter religioso e, em geral, concedido pelos templos por motivos de perseguiçáo religiosa.

Assim, conforme Andrade (2001, pp. 99-125), não é coincidência que a palavra "asilo" seja derivada do grego, porque, na Grécia Antiga, a instituição do asilo foi de extenso uso, sendo concebido como uma noção de inviolabilidade ou de refúgio inviolável, em que o perseguido podia encontrar proteção para sua vida.

Continua o autor manifestando que a prática do asilo se encontra registrada nas velhas normas do antigo Egito e de Roma, e que, durante a Idade Média, com a cristianizaçáo de Roma e o surgimento de uma sociedade perseguidora que pretendia o exílio e a extinção de judeus, hereges e leprosos, gerou uma importante mudança na ocupação do território europeu (Andrade, 2001), a partir de expressivos movimentos de pessoas em procura de proteção.

Nos dias de hoje, milhares de pessoas que fogem de conflitos bélicos e de processos de perseguição têm procurado asilo na Europa. No entanto, o sistema europeu comum de asilo se mostrou incapaz de lidar com esse afluxo de refugiados sem precedentes. Como resposta à crise de refugiados, a Uniáo Europeia tornou a revisão do sistema de asilo uma prioridade, sobretudo para assegurar que as responsabilidades sejam partilhadas de forma justa entre os Estados-Membros.

No âmbito latino-americano, o asilo teve um importante desenvolvimento em direção ao chamado "asilo político", o qual é a base para a inserção dessa instituição na Constituição brasileira e na maioria dos marcos legais e constitucionais da América Latina (Nascimento, 2014 p. 29), que, segundo Andrade (2001), representou o começo do desmembramento normativo da instituição do asilo.

Nesse ponto, um esclarecimento faz sentido a fim de não gerar confusóes conceituais.

Para Medeiros (2017, p. 8), o asilo é uma proteção que a pessoa recebe de um Estado diferente ao Estado de sua nacionalidade ou origem, em funçáo de uma perseguição sofrida. Essa proteção pode ser recebida no próprio território do Estado (asilo territorial) ou em lugares sob sua autoridade (asilo diplomático); por sua vez, o refúgio é um instituto com estatuto próprio, por meio do qual se assegura à pessoa, 
em função de algumas circunstâncias, o status de refugiado (Piovesan, 2014 citado por Medeiros, 2017, p. 64).

Portanto, o refúgio é concedido ao imigrante por fundado temor de perseguição por motivos de raça, religião, nacionalidade, grupo social ou opinióes políticas. No Brasil, a matéria é regulada pela Lei 9.474, de 22 de julho de 1997, que criou o Comitê Nacional para os Refugiados (Conare), e pela Convenção das Naçóes Unidas sobre o Estatuto dos Refugiados, de 28 de julho de 1951. Por sua vez, não existe uma lei específica para tratar os casos de asilo, que é avaliado diretamente pela Presidência da República. Assim, no caso do asilo, as garantias são dadas apenas após a concessão. Antes disso, a pessoa que estiver em território brasileiro estará em situação de ilegalidade. Como já observado, o asilo pode ser de dois tipos: diplomático ou territorial; se concedido, o requerente estará ao abrigo do Estado brasileiro, com as garantias devidas.

Sobre isso, Medeiros (2017) também afirma que, embora se trate de institutos jurídicos com corpos normativos próprios, os dois têm uma mesma origem, essa é o artigo 14 da Declaração Universal dos Direitos Humanos, cujo conteúdo garante a proteção aos cidadãos que precisem se deslocar do país de origem em busca de um lugar para viver com algum grau de paz e segurança.

Entendido o anterior, observe-se igualmente que a natureza do homem como ser social, que implica sua constante comunicação com outros, sua organização e o surgimento de grupos e interesses comuns, está refletida nos diferentes conflitos bélicos, seja por obter a liberdade, seja por garantir maior poder. Alguns desses conflitos foram de escala global e tiveram como consequência um aumento no fluxo das migraçóes e a configuração do refúgio como uma nova instituição de proteção no quadro do Direito Internacional.

A Agência da Organização das Naçóes Unidas para os Refugiados (ACNUR) argumenta que o problema dos refugiados se tornou uma preocupação da comunidade internacional no início do século Xx por questôes humanitárias (ACNUR, 2011, p. 5), resultado principalmente da instabilidade política de alguns países e das hostilidades bélicas que tiveram lugar antes, durante e após a Primeira Guerra Mundial, com o cenário de discussão as atividades da Liga das Naçóes (Andrade, 2001). 
Porém, finalizada a Segunda Guerra Mundial, já no quadro da Organização das Naçóes Unidas (ONU), foi possível adotar o Estatuto dos Refugiados por meio da Convenção de Genebra de 28 de julho de 1951, a qual entrou em vigor em 22 de abril de 1954 (ACNUR, 2011, p. 48.) e que foi fruto da Conferência de Plenipotenciários realizada em Genebra de 2 a 25 de julho de 1951 (Barichello e Araujo, 2015, p. 125).

O desenvolvimento desse Estatuto esteve marcado por duas correntes de pensamento: a) os "universalistas", que entendiam que a Convençáo deveria ser aplicada a todos os refugiados, independentemente da sua origem; b) os "europeístas", que indicavam que a Convenção tinha se limitado aos refugiados dos países europeus (Barichello e Araujo, 2015).

$\mathrm{O}$ artigo $1^{\circ} \mathrm{A}$, parágrafo $2^{\circ}$, da Convenção estabelece as condições de aplicação do status de refugiado, das quais se destacam as seguintes: a) um limite temporal para acontecimentos ocorridos antes de $1^{\circ}$ de janeiro de $1951^{2}$; b) suspeita de perseguição no país da origem; c) motivação da perseguição em questôes relacionadas com raça, religião, nacionalidade, grupo social ou opinióes políticas; d) localização fora do país de origem; e) impossibilidade de voltar ao país ou nấo vontade de voltar em virtude do temor de perseguição.

Além da definição de refugiado acima mencionada, a Convenção contempla alguns direitos para as pessoas que são consideradas como refugiados, tais como o direito de acesso à propriedade móvel e imóvel pelo menos sob as mesmas condiçóes que os estrangeiros (art. 13), o benefício da proteção em matéria de propriedade industrial (art. 14), o direito de associação sem fins políticos (art. 15), o direito de acesso à justiça (art. 16), o direito ao trabalho (arts. 17-19 e 24), a educação e a assistência pública (arts. 22-23), entre outros.

Igualmente, a Convenção reconhece outras questóes importantes que são o núcleo vital do status do refugiado, as quais estão relacionadas com a possibilidade de obter uma identificação por parte do Estado receptor (art. 27), a não aplicaçáo de sançôes para os refugiados em situação irregular no país (art. 31), assim como a proibição de

2 O limite temporal estabelecido na Convenção de 1951 foi abolido pelo Protocolo de 1967, relativo ao Estatuto dos Refugiados, em consideração ao surgimento de novos refugiados após 1º de janeiro de 1951. 
devolução ou expulsão do país, salvo quando estiver envolvida a segurança do país receptor (arts. 32-33).

A importância das anteriores questóes relacionadas com a identificação das pessoas em condição de refugiado radica em que ela permitirá a materialização da maioria dos direitos reconhecidos pela Convenção. Isso porque não resulta aceitável, por questóes humanitárias, que as pessoas que fugiram de condiçóes nas quais sua vida estava em perigo fossem obrigadas a retornar àqueles territórios onde poderiam sofrer qualquer tipo de agressão e, inclusive, perder a vida.

Em suma, com a criação do Estatuto dos Refugiados, buscou-se desenvolver os princípios de solidariedade e cooperação internacional, o que evitaria o surgimento de problemas entre os Estados em razão do aumento de fluxo de migraçóes por questôes internas de um país e por consequência de atos bélicos. Dessa forma, sua aplicação permite garantir os direitos humanos fundamentais das pessoas em condiçốes de vulnerabilidade por motivos de raça, religião, nacionalidade, grupo social ou opiniôes políticas, reconhecendo o caráter social e humanitário que rodeia essa situação de anormalidade.

Contudo, na atualidade, existem "novas" ${ }^{3}$ razóes que levam as pessoas a decidirem pela saída de seu país de origem em massa, que não estão contempladas pelo Estatuto dos Refugiados, o que gera grande dificuldade na hora de determinar se podem ser consideradas como refugiadas ou se, de forma contrária, devem receber um tratamento diferente. Dentro dessas circunstâncias, podemos citar os chamados "migrantes econômicos" e os "deslocados ambientais", os quais serão objeto de estudo mais adiante.

Embora a análise deste artigo esteja focada no refúgio, uma pergunta poderia surgir após identificar a existência de duas normativas internacionais com objetivos semelhantes: por que falar de ampliação do conceito de refugiado e não do instituto do asilo? Pois bem, como acima mencionado, se bem esses institutos tenham mesma origem e finalidade similar, existem algumas diferenças que fazem

3 A denominação de "nova" usada nesta parte, faz referencia especifica ao conteúdo da Convenção de 1951, porque muitas dessas situaçóes objeto de estudo nos seguintes itens, têm origens e antecedentes remotos. 
mais adequado o refúgio para abranger o caso dos migrantes econômicos e dos deslocados ambientais.

Algumas dessas diferenças estabelecidas por Jubilut (2007, p. 50 citado por Medeiros, 2017, pp. 128-129) são: a) o fato de que, no refúgio, exista um órgão internacional encarregado da fiscalização; b) a exigência de que o indivíduo esteja fora do Estado de origem; c) o nascimento de obrigaçóes internacionais para o Estado de acolhida; d) a responsabilidade para o Estado de acolhida de estabelecer políticas de integração local dos refugiados.

Conforme disposto, um órgáo fiscalizador garante unidade de critério na hora de declarar como refugiado a uma pessoa e, portanto, permite que o processo seja mais transparente. Já quanto à necessidade de que o indivíduo esteja fora do Estado, considera-se que esse requisito denota a existência de uma verdadeira tragédia social, cuja abordagem deve fazer uso dos diferentes instrumentos humanitários estabelecidos nos instrumentos internacionais e nas normas nacionais do país receptor.

Além disso, as últimas diferenças listadas permitem maior seguimento do cumprimento dessas obrigaçóes internacionais por parte dos Estados, o que implica inclusive acudir aos tribunais internacionais, assim como melhor e mais adequada proteção das pessoas declaradas como refugiados, já que lhes permitirá recomeçar a vida em condições iguais ou similares daquelas dos cidadãos do país receptor.

Finalmente, uma diferença que permite assegurar que o instituto do refúgio é mais adequado para acolher as novas realidades a serem estudadas nos seguintes itens é a possibilidade de ser concedido de forma coletiva (Medeiros, 2017, p. 130), porque, como será exposto, os casos dos migrantes econômicos e dos deslocados ambientais têm como particularidade a geração de migraçóes em massa e a chegada de grandes fluxos de pessoas, situação que torna muito mais ágil o uso da declaraçáo coletiva da condiçáo de refugiado do que estudar um a um os casos apresentados para o eventual reconhecimento do status de asilado de cada uma das pessoas (Guarín e Aldana, 2016). 


\section{Os Migrantes Econômicos: o Caso da Venezuela}

A existência de migrantes econômicos é inegável, já que é muito comum que pessoas que querem melhorar sua situação econômica e as condiçôes de sustento da sua família decidam começar uma nova vida em outro país com melhores oportunidades de trabalho.

Segundo Bingham (2010, pp. 46-48), por muitos anos, a tendência dos Estados, das organizaçóes internacionais, da academia e de parte das organizaçóes não governamentais tem sido gerar uma divisão entre refugiados e migrantes econômicos com a intenção de só outorgar direitos e medidas de proteção aos primeiros. Entretanto, essa solução ou resposta é igualmente geradora de novos problemas sociais pela irregularidade em que muitas pessoas estariam em razão da negativa do status de refugiado.

De fato, o mesmo autor (2010) aponta que não ser reconhecido como refugiado não pode ser suficiente razão para incluir essas pessoas na mesma categoria de migrantes econômicos, já que muitos fenômenos de migraçóes são mistos, o que vale dizer que existem muitas mais razóes que motivam as pessoas a deixarem seus países e emigrarem.

Nesse sentido, uma das dificuldades neste ponto da análise é a relacionada com aquelas pessoas que, fugindo de condiçóes econômicas deploráveis em seu país e da instabilidade política, procuram melhoria econômica junto com outra grande onda de pessoas oriundas de conflitos bélicos, o que gera um verdadeiro fluxo migratório de proporçóes pouco sustentáveis para os países receptores. Surge disso a pergunta se caberia considerar essas pessoas como refugiados e, portanto, receber um tratamento especial.

Sobre essa questão, Casella (2001, pp. 17-26.) manifesta que, embora no âmbito econômico se apresente dificuldade para definir a existência de refugiados, é pertinente considerar, nessa realidade, a aplicação desse conceito. Ainda, estabelecer a diferença entre refugiado econômico e migrante econômico.

Nessa direção, define o "refugiado econômico" como aquele que se vê diante da impossibilidade total de satisfazer suas necessidades vitais no país de origem e deixa-o em procura de condiçóes que lhe permitam subsistir e desenvolver seus direitos, 
enquanto o "migrante econômico" é entendido como a pessoa que, se bem poderia subsistir em seu país natal, insatisfeito com as condiçóes internas, se desloca para outra regiāo (Casella, 2001).

Dessa forma, surge uma definição ampliada do conceito de refugiado contido na Convenção de 1951? A resposta parece ser afirmativa e, segundo Almeida (2001 pp. 155-167), essa concepção teve sua origem na Convenção da Organização da Unidade Africana, aprovada em 10 de setembro de 1969, cujo artigo $2^{\circ}$ estabelece que o termo "refugiado" deve ser aplicado também a toda pessoa que, por causa de agressão exterior, ocupação ou dominação estrangeira, ou acontecimentos que perturbem gravemente a ordem pública em parte ou a totalidade do país de sua nacionalidade, está obrigada a abandoná-lo.

Por consequência, pode-se identificar que o conceito de refugiado tem experimentado uma revisão e uma ampliação em razão de diferentes causas, uma destas relacionada com a ordem pública interna do país, motivo pelo qual poderia se questionar se for igualmente possível que, dentro das causas desse desenvolvimento do conceito, possam considerar-se inclusive as condições econômicas desfavoráveis do país, derivadas de uma instabilidade política.

Não é uma resposta simples. Verifica-se, na situação exposta, que há categorias de pessoas que não se enquadram na situação típica, clássica de refugiados, mas que reivindicam e precisam de proteção internacional, uma vez que, em seus países de origem, não há condiçóes de vida digna, muitas vezes, sequer de vida.

Para Sousa e Bento (2013, p. 32), o que essas pessoas procuram nada mais é que a efetivação da síntese dos direitos humanos: o direito ao desenvolvimento. Porém, o reconhecimento e a efetivação desse direito passam por questóes extremamente intrincadas.

Um exemplo que pode ser objeto de estudo com a finalidade de resolver a pergunta anterior é a realidade pela qual está atravessando a Venezuela, porque é fato notório que os venezuelanos estão saindo em grande massa de seu país em procura de melhores oportunidades (ввС, 2018), devido a dificuldades de natureza múltipla, econômica, social, humanitária e política, o que leva esse processo migratório a ser 
considerado um dos mais graves da América Latina e comparado à crise de refugiados da Síria (O Globo, 2018).

Um estudo do perfil sociodemográfico e laboral da imigração venezuelana no estado de Roraima, na fronteira brasileira, confirma essas realidades mencionadas, já que $77 \%$ dos migrantes entrevistados indicam como motivo para emigrar a crise econômica e política, sendo o perfil destes predominantemente de população jovem (72 \%), masculina (63\%) e solteira (54\%), dos quais $25 \%$ afirmam pretender retornar à Venezuela e outros $61 \%$ condicionam seu retorno à melhoria das condições econômicas (Simões et al., 2017, pp. 129-133).

Com uma realidade como a venezuelana, onde, além da hiperinflação, há falta de produtos básicos e medicinais para a manutenção de uma vida condigna e onde, desde o ano 2004, quase 2,3 milhóes de pessoas abandonaram o país (ввс, 2018), a vulnerabilidade se acentua com inúmeros abusos e violaçóes de direitos humanos e liberdades, devido ao uso geral e sistemático da força e à detenção e perseguição de pessoas opositoras ao governo Maduro (onU, 2017). Logo, é inevitável pensar se realmente os migrantes venezuelanos são apenas migrantes econômicos ou, ao contrário, nas palavras de Casella (2001), em razão da impossibilidade total de satisfazer suas necessidades vitais em seu país, deveriam ser considerados como verdadeiros refugiados econômicos.

Devido a situaçóes como a exposta acima, o conceito de refugiado precisa ser ampliado assim como aconteceu no caso africano acima mencionado.

No âmbito sul-americano, essa ampliação de conceito não resulta ser desconhecida, porque, em 1984, foi promulgada a Declaração de Cartagena ${ }^{4}$, cuja conclusão número três, que seguia o exemplo da África, recomenda considerar como refugiado aquelas pessoas que deixam seus países fugindo, porque sua vida, segurança e liberdade estão ameaçadas pela violência generalizada, agressão estrangeira, conflitos internos, violação massiva de direitos humanos e outras circunstâncias que perturbam seriamente a ordem pública.

4 Adotada pelo "Colóquio sobre Proteção Internacional dos Refugiados na América Central, México e Panamá: Problemas Jurídicos e Humanitários”, realizado em Cartagena, Colômbia, entre 19 e 22 de novembro de 1984. 
No Brasil, a discussão relativa à ampliação do conceito de refugiado, pelo menos em tese, parece superada, porque, pela Lei. 9.474 de 22 de junho de 1997, se reconhece como refugiado todo indivíduo que, devido à grave e generalizada violaçáo de direitos humanos, é obrigado a deixar seu país de nacionalidade para buscar refúgio em outro país (art. $\left.1^{\circ}, \mathrm{III}\right)$, normatividade que abrange a extensão do conceito proposta pela Declaração de Cartagena.

Em síntese, o caso da Venezuela, estudado neste texto, resulta ser um modelo adequado para o rompimento do paradigma do conceito clássico de refugiado, já que expõe uma realidade humanitária que não pode ser desconhecida pelos Estados, a qual, muito embora não seja de fácil manejo em virtude das questóes internas de cada país, deve ser atendida adequadamente para evitar o surgimento de possíveis casos de xenofobia na sociedade, os quais podem aprofundar a crise social não só dos venezuelanos, mas também dos nacionais dos países receptores 5 .

Neste ponto, vale a pena lembrar que os diferentes migrantes são pessoas vulneráveis, característica que, para Jardim (2017, p. 42), não se deriva do fato de estarem distantes de seus países, senão pela impotência de quem sai de sua comunidade e se encontra ante uma eventual desproteçáo tanto social como jurídica. Nesse sentido, seu tratamento merece especial atenção, ainda mais quando existe a impossibilidade de retorno.

Portanto, apesar de ampliar o alcance da expressão "refugiados econômicos", trata-se de uma questâo delicada, uma vez que não sáo considerados refugiados em sentido clássico nem migrantes comuns, pois lhes falta o elemento volitivo que caracteriza as migraçóes em sentido amplo. Assim, é fundamental diferenciar que, enquanto o migrante econômico deixa seu país de origem apenas em busca de melhores condiçôes de vida, o refugiado econômico deixa seu Estado por uma questáo de sobrevivência.

5 Segundo dados da ACNUR publicados em 8 de novembro de 2018, quase 3 milhóes de venezuelanos estâo fora do país em condição de refugiados ou migrantes, destes 2,4 milhôes na América Latina e 600 mil em outras regiōes. Na América do Sul, a Colômbia recebeu mais de 1 milhão de venezuelanos, seguida do Peru, com 500 mil, do Equador, com mais de 220.000, da Argentina, com 130.000, do Chile, com mais de 100.000, e do Brasil, com 85.000 (ACNUR, 2018). 


\section{Os Deslocados Ambientais no Regime de Refugiados}

A variabilidade dos fenômenos naturais, cujas consequências são cada vez maiores e mais fortes devido às mudanças climáticas e ao aquecimento global, trouxe o conceito de deslocados ambientais no âmbito dos direitos humanos e da proteção dos refugiados.

Como bem observam Loureiro e Rei (2018, pp. 396-297), as guerras ou a falta de proteçâo do Estado de origem sempre foram as principais causas históricas da quase totalidade das diásporas de pessoas que se deslocavam para outros países por instinto de sobrevivência. Assim, em temas migratórios, o homem legislou somente considerando o próprio homem como agente perseguidor, o único capaz de gerar essa espécie de êxodo.

Para os autores (Loureiro e Rei, 2018), a partir do momento em que a relação do homem com a natureza assumiu uma postura extremamente impactante, apta a romper as relaçóes de equilíbrio dos ecossistemas, surge a natureza como o "gatilho" de disparo de processos migratórios. E fenômenos naturais contemporâneos, como os efeitos da mudança climática, começaram a se mostrar capazes de produzir mais deslocamentos humanos do que qualquer déspota jamais provocou ao longo da História.

Assim, Casella (2001) entende como deslocados ambientais aquelas pessoas que, em virtude de catástrofes ambientais, como terremotos, secas e inundaçóes, têm que deixar suas regiốes ${ }^{6}$ ou seu país da origem. Ou seja, deslocados ambientais são pessoas que, por motivos de desastre ambiental natural ou causados pelo homem, são obrigadas a deixar sua localidade habitual, migrando para lugares onde possam ser mantidas em segurança, no que concerne aos fatores ambientais que as atingiu, seja no país de origem, seja no exterior.

Como é natural, o conceito de deslocado ambiental deve incorporar também todos os efeitos e fenômenos altamente agravados pelas mudanças do clima, tais como as temperaturas extremas, o degelo dos polos, o desaparecimento de ilhas, os furacóes,

6 Como exemplo de deslocados ambientais ao interior do país, Casella (2001) faz referência ao fluxo de nordestinos para o Sudeste do Brasil e, em especial, para São Paulo. 
os deslizamentos de terra, a desertificação, a escassez de água, o desmatamento, a perda de biodiversidade e a contaminação de áreas, entre outros.

Para Ruppel (2013, p. 42), ainda que não haja certeza sobre o que exatamente a mudança climática significará para os padróes de migração, parece haver consenso de que as mudanças climáticas levarão, ao longo do tempo, a deslocamentos populacionais, os quais estão intimamente relacionados com o conceito de segurança humana e dos países (Leroy e Gebresenbet, 2013, pp. 689-692)7.

Embora as mudanças climáticas e suas consequências sejam fenômenos recentes, autores como Fernandes (2014, pp. 30-34) asseguram que o deslocamento forçado de pessoas por causas ambientais não é uma novidade, já que, desde as primeiras sociedades pastorais, os fatores ambientais e climáticos influenciaram a escolha do local de fixação humana.

Além disso, a mesma autora (2014) aponta que as causas do deslocamento ambiental, em conjunto com condiçóes de pobreza, debilidade da infraestrutura pública de proteção social e baixa participação social, geram cenários de alta vulnerabilidade para a criação de verdadeiras crises humanitárias, colocação compartilhada por Cortes (2016).

Assim, embora as causas ambientais que podem gerar um deslocamento forçado de pessoas sejam diversas, pergunta-se, entáo, se esse outro movimento ou migraçáo em massa pode ser considerado como suporte para uma ampliação do conceito clássico de refugiados.

Sobre esse tópico, a expressão "refugiados ambientais" foi acunhada pela primeira vez pelo El-Hinnawy (1985 citado por Cardy, 1994, p. 2), que, em um relatório para o Programa das Naçóes Unidas para o Meio Ambiente, em 1985, indicou que como tais devem ser consideradas aquelas pessoas que são forçadas de forma temporal ou permanente a deixar sua terra tradicional como consequência de fortes mudanças ambientais que ameaçam sua existência ou afetam seriamente sua qualidade de vida.

7 Sobre os nexos entre as mudanças climáticas e a segurança, os autores citados mencionam como diferentes agências de segurança de diferentes lugares, como Estados Unidos e União Europeia, ordenaram a elaboração de estudos para definir o impacto das mudanças climáticas na segurança. 
De fato, os refugiados ambientais podem, segundo El-Hinnawy (1985 citado por Borràs, 2006, p. 95), ser classificados em três grandes grupos:

(a) os forçados a se deslocar temporalmente pelas pressóes ambientais e que provavelmente retornem ao habitat original;

(b) os deslocados permanentes como consequência de mudanças igualmente permanentes em seus territórios;

(c) os deslocados permanentes que procuram uma melhor qualidade de vida, porque seu habitat original não permite a satisfação de suas necessidades vitais devido à degradação progressiva dos recursos naturais.

Além disso, com base na anterior definição, autores como Granado e De Oliveira (2016, pp. 165-166) fazem uma diferença entre "refugiado ambiental" e "flagelado ambiental", entendendo o primeiro como aquelas pessoas obrigadas a deixar de forma definitiva seu habitat natural por intempéries da natureza e como flagelados todas as vítimas momentâneas de desastres ambientais, que podem retornar a seu lugar da origem quando o problema tiver sido resolvido (Garzón, 2013).

Assim, no caso dos haitianos que sofreram os efeitos do terremoto de 2010 e chegaram posteriormente ao Brasil, o Conare, embora tenha reconhecido as grandes dificuldades sofridas por esses migrantes, determinou que náo poderiam receber o tratamento de refugiados (Fernandes, 2014, pp. 82-84) à luz do conteúdo da Convenção de 1951 e da Lei 9.474/1997, mencionadas no anterior item. O Conselho Nacional de Imigração do Brasil, porém, definiu um mecanismo próprio de tratamento para os haitianos, baseado na aplicação da proteção complementar humanitária ${ }^{8}$.

Esse fato comprova que, apesar de o Brasil ter aceitado os haitianos deslocados através de previsão em sua legislação, é necessária e oportuna uma discussão internacional ${ }^{9}$

8 O mecanismo de admissáo de migrantes haitianos no Brasil incluiu: a) a apresentação do requerimento na embaixada do Brasil em Porto Príncipe, com a finalidade de desestimular a prática de aproveitadores; b) uma previsão de um limite de um mil e duzentos vistos permanentes anuais. (Fernandes, 2014).

9 Como iniciativa específica de marco jurídico para a proteção e o reconhecimento das vítimas de deslocamentos ambientais com uma abordagem pautada nos direitos humanos, destaca-se o Projeto de Convenção relativo ao 
sobre a ampliação do conceito de refugiado, porque as causas ambientais que geram deslocamentos forçados de pessoas, juntamente com as condiçóes sociais, econômicas e políticas do país de nacionalidade, muitas vezes, impossibilitam que elas tenham um desenvolvimento condigno da sua vida, colocando-as em condiçóes de vulnerabilidade e iminente violaçâo de seus direitos humanos fundamentais.

Apesar de o atendimento de refugiados não estatutários ${ }^{10}$ poder representar um alto custo para muitos países, em consideração às condições atuais de mudanças climáticas, nenhum país está livre de sofrer qualquer tipo de catástrofe ou fenômeno ambiental. E são aqueles mais vulneráveis os que também possuem graves fraturas sociais e econômicas, sendo necessária a ativaçáo dos princípios de solidariedade e cooperaçáo internacional não só quando das catástrofes, mas também de maneira preventiva, para evitar as consequências negativas, e sobretudo tentando mitigar as crises humanitárias produto de sua ocorrência.

Nesse sentido, Fernandes (2014, pp. 86-87) faz um chamado para que o conceito de refugiado seja alargado, já que uma interpretação atual dessa instituição do Direito Internacional e dos Direitos Humanos deve considerar que, embora no século xx a maior parte das pessoas tenha sido morta por consequência de conflitos bélicos, hoje, no século XXI, a maior parte é lesada pelas condiçóes em que vivem.

Dessa forma, dentro das condiçóes de vida que podem ferir as pessoas e seus direitos, é objetivamente possível considerar que os efeitos das mudanças climáticas em muitos casos não só impedem o normal desenvolvimento das vidas dos mais vulneráveis, como também podem ocasionar a morte destes e a desintegração de núcleos familiares.

A propósito, observa-se que o Parlamento Europeu declarou, em 2011, ser necessário um estatuto internacional de refugiado climático e ambiental, e, em 2015, solicitou que

Estatuto Internacional dos Deslocados Ambientais (Projeto de Convençáo ou Projeto de Limoges), elaborado pelo Centro de Pesquisas Interdisciplinares em Direito Ambiental, Planejamento e Urbanismo, do Centro de Pesquisas sobre os Direitos das Pessoas e do Observatório das Mutaçōes Institucionais e Jurídicas da Universidade de Limoges, França, e do Centro Internacional de Direito Comparado do Ambiente.

10 Aqueles que recebem o status de refugiado com base no conteúdo da Convençáo de 1951 e seu Protocolo de 1967. 
o problema fosse considerado, lamentando que o status de "refugiado climático" ainda não tivesse sido reconhecido (Cavedon-Capdeville, Prieur e Lavieille, 2018, p. 200).

Agora, embora exista certo grau de consenso em que as problemáticas ambientais atuais estão contribuindo de forma importante no aumento dos fenômenos migratórios, a solução da ampliação do conceito de refugiado, como manifestada pelo Parlamento Europeu, náo é compartilhada por alguns autores. Cunha (2012, pp. 109-110), por exemplo, mudou sua própria visão, que previamente reconhecia a necessidade dessa ampliação, para, posteriormente, indicar que essa colocação é pouco produtiva, porque o contexto internacional não parece favorável e não tinha existido oportunidade para a ampliação do conceito embora quando o mundo passava por graves recessóes econômicas que intensificaram os movimentos em massa.

Outros autores observam ser muito complicada a classificação como refugiados ambientais, sob o Estatuto do Refugiado, daquelas pessoas obrigadas a se deslocarem por causas ambientais e lembram que, de qualquer forma, os Estados devem assegurar que todas as pessoas, cidadãos e não cidadãos classificados como refugiados ou migrantes ambientais ou pessoas que fogem de conflitos armados contra a pobreza, receberão a salvaguarda de sua dignidade humana básica e o respeito pelos seus direitos humanos fundamentais (Ruppel e Van Wyk, 2013, p. 811).

Neste momento, resulta relevante ver como, apesar da gravidade das realidades humanitárias derivadas dos fenômenos naturais atuais, predomina o olhar meramente normativo para desconhecer uma mudança dos clássicos conceitos jurídicos, esquecendo que o aproveitamento de um sistema previamente constituído, como é o sistema internacional dos refugiados, pode ser ampliado para dar proteção e incluir novas pessoas, podendo ser muito mais eficiente na hora da obtenção de resultados do que pensar em criar novos regimes internacionais ou regionais exclusivos para a problemática dos deslocados ambientais, embora essas sejam opçóes válidas.

Como bem destacam Loureiro e Rei (2018, p. 397), situaçóes novas exigem novos olhares jurídicos para regulá-las. A figura do refugiado sofreu mutação devido à alteração do agente perseguidor, pois, tradicionalmente, o dilema dos refugiados estava — e ainda está — relacionado a problemas de cunho político, econômico e 
social. Eis que, entretanto, agora é o homem que causa a mudança climática; ele é o “agente" causador das grandes deslocações (Barragán, 2016).

Em suma, ainda que não se desconheça o forte debate acadêmico ao redor da proposta de ampliar o conceito tradicional de refugiado ${ }^{11}$, com fins de introduzir nele novas classes de pessoas forçadas a se deslocar, não é possível esquecer a realidade e as histórias pelas quais o tópico se tornou tema de debate.

Com o anterior, é possível entender que a existência dessa realidade é o suporte em si mesmo para a reflexão, a evolução e a transformação de um regime de proteção que não ignore o tratamento das pessoas que carecem do seu sistema de proteção, o que representa um bom exemplo da constante evoluçáo do Direito Internacional dos Direitos Humanos (Molina, 2016).

Embora a proposta de ampliação ou alongamento do conceito de refugiado a partir do âmbito ambiental tenha posiçôes contra no mesmo sistema internacional de proteção dos refugiados ${ }^{12}$, essa circunstância permite concluir, de acordo com Ramos (2011, p. 81), que o problema em avançar no tema é de ordem política, e não jurídica.

A mesma autora manifesta que resulta importante repensar e revisar conceitos, o papel dos atores e a própria ordem internacional (Ramos, 2011, p. 121), atividades que permitirão obter um quadro de proteçâo integral das pessoas descoladas como consequência de fatores ambientais em geral, o que representaria igualmente um avanço fundamental na garantia dos direitos fundamentais (Valderrama, Téllez e Blanco, 2018).

Nessa mesma linha e em face da governança global, Felix (2015, p. 32) propóe que, devido a uma interdependência entre os países em matéria ambiental, uma soluçấo para as migraçóes motivadas por causas ambientais deve demandar a

11 Richard Black é considerado, pela professora Ramos, como um dos autores mais críticos no debate sobre refugiados ambientais, devido a que ressalta as dificuldades práticas ante a aplicação da pluralidade de definiçôes e terminologias, o que revelaria a falta de precisão e a pouca utilidade desse fenômeno (Ramos, 2011, p. 81).

12 "Em manifestação oficial sobre o tema, o ACNUR, apesar de reconhecer expressamente o vácuo normativo $e$ a necessidade de proteçấo internacional em relação a "certos grupos de migrantes", considera que eventual renegociação do regime de 1951 poderia resultar no indesejável enfraquecimento do regime internacional vigente (Ramos, 2011, p. 119). 
revisão de institutos já consolidados, como o Estatuto dos Refugiados ou mesmo a reestruturação do sistema de governança ambiental global.

\section{Conclusóes}

O fenômeno migratório não é novo. Há muito tempo, ele se desenvolve sob diferentes óticas, com a necessidade de constante revisão nas respostas normativas a partir do Direito Internacional, o que permitiu o nascimento de institutos jurídicos encarregados de garantir a proteção e os direitos fundamentais das pessoas que, contra sua vontade, tiveram e têm que deixar seus países de origem. Um exemplo dessas respostas são os institutos do asilo e do refúgio, apesar de parecidos quanto à origem fática e normativa, assim como à sua finalidade, possuem igualmente algumas diferenças estruturais que impedem falar deles como se fossem um só.

Ainda que os institutos criados pelo Direito Internacional contem com uma boa aceitação e resultados em matéria de proteção, hoje, existem realidades complexas que fazem repensar seu conteúdo e alcance, como acontece com a instabilidade econômica e política interna dos países e a ocorrência de fenômenos naturais cada vez mais intensos devido às mudanças climáticas.

Nesse sentido, existe um debate doutrinário em torno da mudança ou não do conceito clássico de refugiado a fim de incluir as pessoas atingidas por essas realidades mencionadas, dando ênfase a que o refúgio seria o instituto jurídico que mais possibilidades teria de abrangê-las, em razão de algumas características especiais, tais como: a) o fato de que, no refúgio, exista um órgão internacional encarregado da fiscalização; b) a exigência de que o indivíduo esteja fora do Estado de origem; c) o nascimento de obrigaçóes internacionais para o Estado de acolhida; d) a responsabilidade para o Estado de acolhida de estabelecer políticas de integração local dos refugiados; e) a possibilidade de ser outorgado de forma coletiva.

Contudo, o regime de proteção dos refugiados em sua concepção clássica não permite a inclusão dessas pessoas atingidas pelos novos fatores já citados, situação que requer a retomada de um amplo debate, com a finalidade de construir um consenso e, 
se possível, chegar a um acordo que garanta os direitos humanos daquelas pessoas forçadas a deixar seu território e com pouca ou nenhuma possibilidade de retornar.

Embora o regime dos refugiados seja muito fechado, existem exemplos, como o do Brasil, nos quais, a partir da proteção complementar humanitária, foi possível garantir direitos a essas pessoas que, sob a concepçáo clássica de refugiado, não teriam direito a obter esse status, deixando entrever uma evidente evolução e um avanço importante no caminho da ampliação e na ampliação do conceito tradicional de refugiado.

Em suma, dentro do regime de proteção dos refugiados, o fenômeno das grandes migraçóes em massa e, especialmente, o elemento de perseguição das pessoas que abandonam seus países, reivindica uma concepção flexível, que permita reconhecer o status de refugiado às pessoas deslocadas por razóes econômicas, sociais e políticas internas do país, assim como àquelas obrigadas a atravessar as fronteiras como consequência de fenômenos ambientais e mudanças climáticas.

Assim, o estudo dessas novas circunstâncias, que geram migrações em massa, deve partir do mesmo conteúdo principiológico, os princípios do direito internacional de cooperação e solidariedade, para abraçar o entendimento da impossibilidade de retorno dos afetados ao seu país da origem e, assim, de continuar com o direito ao desenvolvimento de suas vidas.

Finalmente, é importante mencionar que as grandes migraçóes de pessoas são uma problemática global não restrita a uma região, motivo pelo qual, para a obtenção de consensos e acordos sobre o tema, é necessário procurar soluçôes entre os diferentes atores que fazem parte do cenário internacional, entendendo que os tempos que originaram o instituto do refúgio mudaram e que a proteção de pessoas em condiçóes de vulnerabilidade deve ser encarada com olhos do século XXI.

De acordo com o ACNUR, hoje mais de 68,5 milhóes de pessoas ao redor do mundo podem ser enquadradas como "deslocados forçados", sem necessariamente ser devido a conflitos armados ou perseguições políticas (ACNUR, 2017). Sabe-se que a problemática é tema de longas discussóes e que ainda está longe de um enfrentamento satisfatório, mas, nem por isso, os Estados, as organizaçôes internacionais e os novos atores internacionais podem ignorar as pretensóes nesse sentido. 


\section{REFERÊNCIAS}

ACNUR. (1984). Declaração de Cartagena de 1984 [PDF]. Recuperado de: http://www.acnur. org/fileadmin/Documentos/portugues/BD_Legal/Instrumentos_Internacionais/Declaracao_de_Cartagena.pdf

acnur. (2011). Manual de Procedimentos e Critérios para a Determinação da Condição de Refugiado. De acordo com a Convenção de 1951 e o Protocolo de 1967 relativos ao Estatuto dos Refugiados. ACNUR.

ACNUR. (2017). Tendencias Globales: Desplazamiento forzado en 2017 [PDF]. Recuperado de: https://s3.amazonaws.com/unhcrsharedmedia/2018/Global_Trends_Forced_Displacement_in_2017/TendenciasGlobales_2017_web.pdf

ACNUR. (2018) La cifra de personas refugiadas y migrantes venezolanas alcanzan los 3 millones. Recuperado de: https:/www.acnur.org/noticias/press/2018/11/5be443b54/la-cifra-depersonas-refugiadas-e-inmigrantes-venezolanas-alcanza-los-3.html

Almeida, G. (2001). A Lei 9.474/97 e a Definição Ampliada de Refugiado: Breves consideraçóes. Em: Araujo, N. de; Almeida, G. (Coord.). (2001). O direito internacional dos refugiados: uma perspectiva brasileira. (pp. 155-167). Rio de Janeiro: Renovar.

Andrade, J. (2001). Breve reconstituição histórica da tradição que culminou na proteção internacional dos refugiados. Em: Araujo, N. de; Almeida, G. (Coord.) (2001). O direito internacional dos refugiados: uma perspectiva brasileira. (pp. 99-125). Rio de Janeiro: Renovar.

Aristóteles. A política. (pp. 11) [PDF]. Recuperado de: http://www.dhnet.org.br/direitos/ anthist/marcos/hdh_aristoteles_a_politica.pdf

Barichello, S.; Araujo, L. (2015). Aspectos Históricos da Evolução e do Reconhecimento Internacional do Status de Refugiado. Revista do Direito Universidade de Santa Cruz do Sul, 2(46), 104-134. DoI: http://dx.doi.org/10.17058/rdunisc.v2i46.4507

Barragán D. (2016). La construcción de la mentalidad democrática como necesidad en el posconflicto en Revista Via Inveniendi et Iudicandi, 11(1), 37-57.

Barreto, L. (2010). A Lei Brasileira de Refúgio - Sua História. Em: Barreto, L. (Org.). Refúgio no Brasil: A proteção brasileira aos refugiados e seu impacto nas Américas (pp. 12). Brasília: ACNUR, Ministério da Justiça. 
ввс. (2018). Venezuela: 3 gráficos que muestran la enorme dimensión del éxodo en los últimos años por culpa de la crisis. Recuperado de: https://www.bbc.com/mundo/noticias-america-latina-45262411

Bingham, J. K. (2010). Priorizando Necessidades: Uma abordagem baseada em direitos para as Migraçóes Mistas. Em Instituto de Migraçóes e Direitos Humanos (Ed.), Cadernos de Debate: Refúgio, Migraçoos e Cidadania (Vol. 5, pp. 46-48). Brasília: Instituto de Migraçóes e Direitos Humanos. Recuperado de: https://www.acnur.org/fileadmin/Documentos/portugues/Publicacoes/2011/Caderno_de_Debates_5.pdf

Borràs, S. P. (2006). Refugiados ambientales: El nuevo desafío del derecho internacional del medio ambiente. Revisa de Derecho Universidad Austral de Chile. XIX(2), 85-108. DOI: http://dx.doi.org/10.4067/S0718-09502006000200004

Brasil. Congresso Nacional Lei n. 9474 de 22 de junho de 1997 "Define mecanismos para a implementação do Estatuto dos Refugiados de 1951, e determina outras providências”. Coleção de Leis da República Federativa do Brasil, Brasília, DF, DOu de 23.7.1997

Cardy, F. (1994). Environment and Forced Migration: A review. For the Last Plenary Session of the Fourth International Research and Advisory Panel Conference. Recuperado de http:// repository.forcedmigration.org/show_metadata.jsp?pid=fmo:1158

Casella, P. (2001). Refugiados: conceito e extensão. Em N. de Araujo e G. Almeida (Coords.), $O$ direito internacional dos refugiados: uma perspectiva brasileira (pp. 17-26). Rio de Janeiro: Renovar.

Cavedon-capdeville, F., Prieur, M., e Lavieille, J. (2018). O Projeto de Convenção de Limoges sobre o Estatuto Internacional dos Deslocados Ambientais. Em L. Jubilut et al., Refugiados Ambientais. Boa Vista: Editora da Universidade Federal de Roraima.

Cortes, S. (2016). Derechos humanos en las políticas de paz y posconflicto en Colombia. Via Inveniendi et Iudicandi, 11(1), 129-145. Recuperado de http://revistas.usantotomas.edu. co/index.php/viei/article/view/2926/2798

Cunha, A. P. da. (2012). "Refugiados ambientais"? Em ACnur e Instituto de Migraçóes e Direitos Humanos, Cadernos de Debate: Refúgio, Migraçôes e Cidadania (Vol. 7, pp. 109-110). Brasília: Instituto de Migraçóes e Direitos Humanos. Recuperado de: https:// www.acnur.org/portugues/wp-content/uploads/2018/02/Caderno-de-Debates-07_ Ref \%C3 \%BAgio-Migra \%C3 \%A7 \%C3 \%B5es-e-Cidadania.pdf 
Felix, R. (2015). Refugiados Ambientais e Governança Global. Em A. Gonçalves e F. Rei (Org.), Governança Global: Aplicaçôes em temas internacionais. Santos: Editora Universitária Leopoldianum.

Fernandes, E. (2014). Meio Ambiente e Direitos Humanos: O deslocamento de pessoas por causas ambientais agravadas pelas mudanças climáticas. Curitiba: Juruá.

Garzón, E. (2013). Globalización del derecho, fetichismo legal el velo de los Derechos Humanos. Revista Verba Iuris, 30, 169-181. Recuperado de https://revistas.unilibre.edu.co/ index.php/verbaiuris/article/view/2154/1636

Granado, K., e Oliveira, C. (2016). Políticas migratórias para refugiados ambientais na União das Nações Sul-Americanas. Em M. L. Granziera e F. Rei (Orgs.), Anais do IV Congresso Internacional de Direito Ambiental Internacional: Encontro Internacional sobre Estratégia e Economia Azul. Governança Ambiental Global. 26, 27 e 28 de out. 2016. Universidade Católica de Santos: Editora Universitária Leopoldianum,

Guarín, E. A., e Aldana, J. (2016). Estado jurisdiccional y bien común. Revista Verba Iuris, 11(36), 13-26.

Jardim, T. (2017). A Lei Migratória e a Inovação de Paradigmas. Em: ACnur e Instituto de Migrações e Direitos Humanos, Cadernos de Debate: Refúgio, Migrações e Cidadania (Vol. 12, pp. 17-46). Brasília: Instituto de Migraçóes e Direitos Humanos. Recuperado de https:/www.acnur.org/portugues/wp-content/uploads/2018/02/Caderno-de-Debates-12_Ref\%C3\%BAgio-Migra\%C3\%A7\%C3\%B5es-e-Cidadania.pdf

Loureiro, J., e Rei, F. (2018). Tuvalu: Atlântida Contemporânea. Em L. Jubilut et al., Refugiados Ambientais. Boa Vista: Editora da Universidade Federal de Roraima.

Molina González, Y. (2016). Derecho penal del enemigo y dignidad humana. Revista Verba Iuris, $11(36), 135-146$.

Medeiros, F. (2017). Asilo e Refúgio: Semelhanças e diferenças entre dois institutos de proteção humanitária. Rio de Janeiro: Editora Lumen Juris.

Nascimento, L. (2014). A cidadania dos Refugiados No brasil (2. a ed.). São Paulo: Verbatim.

O Globo. (2018). Crise humanitária venezuelana jáafeta o continente. Recuperado de: https://oglobo.globo.com/opiniao/crise-humanitaria-venezuelana-ja-afeta-continente-22406678 
ONU. (1951). Convenção de 1951 relativa ao estatuto dos refugiados [PDF]. Recuperado de: http://www.acnur.org/fileadmin/Documentos/portugues/BDL/Convencao_relativa_ ao_Estatuto_dos_Refugiados.pdf

ONu. (1967). Protocolo de 1967 relativo ao Estatuto dos Refugiados [PDF]. Recuperado de: http://www.acnur.org/fileadmin/Documentos/portugues/BDL/Protocolo_de_1967_ Relativo_ao_Estatuto_dos_Refugiados.pdf

Onu. (2017). Oficina del Alto Comisionado para los Derechos humanos. Venezuela: Las violaciones de derechos humanos apuntan a una "politica de represión" - Informe de la $O N U$. Recuperado de: https://www.ohchr.org/SP/NewsEvents/Pages/DisplayNews. aspx?NewsID=22007eLangID=S

Patarroyo S e Benavides P (2014). Rupturas Asignificantes: Revisiones críticas en torno al derecho. Revista Via Inveniendi et Iudicandi, 9(1), 7-31.

Ramos, É. (2011). Refugiados Ambientais: Em busca de reconhecimento pelo Direito Internacional (Tese de Doutorado). Universidade de São Paulo: São Paulo. Recuperado de: http:// www.acnur.org/fileadmin/Documentos/portugues/eventos/Refugiados_Ambientais.pdf

Ruppel, O. (2013). Intersections of Law and Cooperative Global Climate Governance Challenges in the Anthropocen. Em O. Ruppel, C. Roschmann, e K. Ruppel-schlichting (Eds.), Climate Change: International Law and Global Governance. Volume II: Policy, Diplomacy and Governance in a Changing Environmental. Baden-Baden: Nomos Verlagsgesellschaft.

Ruppel, O., e Van Wyk, S. (2013). Climate-change-induced Movement of Persons in Africa: Human Rights Responses to Aspects of Human Security. Em O. Ruppel, C. Roschmann, e K. Ruppel-schlichting (Eds.), Climate Change: International Law and Global Governance. Volume II: Policy, Diplomacy and Governance in a Changing Environmental. Baden-Baden: Nomos Verlagsgesellschaft.

Simôes, G. et al. (2017). Perfil sociodemográfico e laboral da imigração venezuelana: resumo executivo. Em: ACNur e Instituto de Migraçôes e Direitos Humanos, Cadernos de Debate: Refúgio, Migraçóes e Cidadania (Vol. 12, pp. 129-136). Brasília: Instituto de Migraçóes e Direitos Humanos. Recuperado de https://www.acnur.org/ portugues/wp-content/uploads/2018/02/Caderno-de-Debates-12_Ref\%C3\%BAgioMigra\%C3\%A7\%C3\%B5es-e-Cidadania.pdf 
Sousa, M., e Bento, L. (2013). Refugiados econômicos e a questão do direito ao desenvolvimento. Revista de Direito Cosmopolita, 1(1), 25-47. Dor: https://doi.org/10.12957/ cosmopolitan.2013.5834

Tirado M, Bedoya J., e Blanco A. (2016). Bioética y transhumanidad: Hacia una aproximación al consumo de sustancias nootrópicas en el campo académico. Em Bioética y Docencia (pp. 91.119). Bogotá: Editorial Ibáñez. Recuperado de https://repository.usta. edu.co/handle/11634/1527

Valderrama I, Téllez, R., e Blanco C. (2018). La incertidumbre de las victimas dentro del acuerdo para la construcción de una paz estable y duradera. Em Tendencias actuales de los Derechos Humanos y el Derecho Internacional Humanitario en Colombia (pp. 83-103). Recuperado de https://repository.usta.edu.co/handle/11634/13049 